\title{
PHYSIOLOGICAL INDICATORS OF SCHOOLCHILDREN OF 7-12 YEARS OF AGE PECULIAR TO MENTAL ARITHMETIC SESSIONS COMBINED WITH ATTENTION SWITCHING PHYSICAL EXERCISES
}

\author{
Gorelik W1凶, Filippova SN², Knysheva TP \\ ${ }^{1}$ Department of Adaptive Physical Culture, Sports and Tourism, \\ Institute of Physical Education and Sports, Togliatti state University, Togliatti \\ ${ }^{2}$ Department of Adaptive Physical Culture and Medical and Biological Disciplines, \\ Institute of Natural Sciences and Sports Technologies, Moscow City pedagogical University, Moscow \\ ${ }^{3}$ «Eureka» intellectual development center, Togliatti
}

\begin{abstract}
Present day education routines subject schoolchildren to considerable loads associated with studying. This research effort aimed to study the effect attention switching physical exercises (the type peculiar to the mental arithmetic curricula) have on heart rate, adaptation abilities, stress resistance, higher mental functions and conditioned reflex activity of children. Examining 124 schoolchildren aged 7-9 and 10-12 years, we applied the pedagogical experiment method that includes benchmarking, formation and control stages, as well as a number of psychological methods: short-term, associative and image memory diagnostics; Bourdon-Wiersma test; search for logical solutions; evaluation of motor skills. Varicard 2.51 was used to assess functions of the cardiovascular system and other physiological state indicators. At the benchmarking stage, we discovered the differences in higher mental functions conditioned by age and gender. Girls aged 7-9 had their memory, attention, ideation indicators 20-40\% higher than boys of the same age. Boys aged 10-12 had their higher mental functions developed 10-30\% better than girls of the same age. At the formation stage, we registered the optimizing effect attention switching physical exercises have on information processing speed and memorizing effectiveness: corresponding indicators increased 1.5-2 times (7-9 y.o., both genders) and 1.2-1.5 times (10-12 y.o., both genders), accordingly. It was concluded that adding the attention switching physical exercises to mental arithmetic curricula makes training sessions more effective.
\end{abstract}

Keywords: schoolchildren, cognitive sphere, cognitive activity, functional activity of CVS, age psychology, mental arithmetic

$\triangle$ Correspondence should be addressed: Victor V. Gorelik

Belorusskaya 14, Togliatti, 445020; lecgoy@list.ru

Received: 18.05.2018 Accepted: 06.10.2018

DOI: 10.24075/brsmu.2018.057

\section{ОСОБЕННОСТИ ФИЗИОЛОГИЧЕСКИХ ПОКАЗАТЕЛЕЙ ШКОЛЬНИКОВ 7-12 ЛЕТ ПРИ ЗАНЯТИЯХ МЕНТАЛЬНОЙ АРИФМЕТИКОЙ, ВКЛЮЧАЮЩИХ ФИЗИЧЕСКИЕ УПРАЖНЕНИЯ С ПЕРЕКЛЮЧЕНИЕМ ВНИМАНИЯ}

\author{
В. В. Горелик ${ }^{1}$, С. Н. Филиппова ${ }^{2}$, Т. П. Кнышева ${ }^{3}$ \\ ${ }^{1}$ Кафедра адаптивной физической культуры, спорта и туризма, \\ Институт физической культуры и спорта, Тольяттинский государственный университет, Тольятти \\ ${ }^{2}$ Кафедра адаптивной физической культуры и медико-биологических дисциплин, \\ Институт естествознания и спортивных технологий, Московский городской педагогический университет, Москва \\ ${ }^{3}$ Центр интеллектуального развития «Эврика», Тольятти
}

\begin{abstract}
В условиях современного образования школьники подвергаются большим учебным нагрузкам. В связи с этим целью работы было изучить влияние физических упражнений с переключением внимания, используемых на занятиях ментальной арифметикой, на показатели сердечного ритма, адаптационные возможности, стрессоустойчивость, характеристики высших психических функций и условно-рефлекторной деятельности детей. При обследовании 124 школьников 7-9 лет и 10-12 лет использовали метод педагогического эксперимента, включающего констатирующий, формирующий и контрольный этапы, а также ряд психологических методик: диагностику кратковременной ассоциативной и образной памяти; корректурную пробу Бурдона; поиск логических решений; определение моторной одаренности. Для диагностики функционального состояния сердечно-сосудистой системы и других показателей физиологического состояния использовали программно-аппаратный комплекс «Варикард 2.51». На констатирующем этапе у школьников выявлены половозрастные различия высших психических функций. У девочек 7-9 лет показатели памяти, внимания, мышления были выше на 20-40\%, чем у мальчиков этого возраста. У мальчиков 10-12 лет отмечался рост показателей высших психических функций по сравнению с девочками того же возраста на 10-30\%. На формирующем этапе показано оптимизирующее воздействие двигательных упражнений с переключением внимания на скорость переработки информации и продуктивность запоминания, показатели которых увеличивались у детей обоего пола в 1,5-2 раза (7-9 лет) и в 1,2-1,5 раза (10-12 лет). Сделан вывод, что включение физических упражнений с переключением внимания повышает эффективность обучения ментальному счету.
\end{abstract}

Ключевые слова: школьники младших классов, когнитивная сфера, познавательная активность, функциональная активность сердечно-сосудистой системы, возрастная психофизиология, ментальная арифметика

$\bowtie$ Для корреспонденции: Виктор Владимирович Горелик

ул. Белорусская, д. 14, г. Тольятти, 445020; lecgoy@list.ru

Статья получена: 18.05.2018 Статья принята к печати: 06.10.2018

DOI: $10.24075 /$ vrgmu.2018.057 
Present day school curricula imply constant intensification of studying and growing volumes of information schoolchildren have to process. Extended educational activities and supernormal educational techniques utilized therein add to the load. Such conditions call for better control over adaptation capabilities, their practical application and general health of schoolchildren [1-5]. Modern psychophysiology holds vegetative balance as an integrated indicator of adaptation in the context of various activities, including studying.

It was found that psychophysical stress can disbalance sympathetic and parasympathetic regulation links and bring sympathicotonia to the foreground, which signals of imbalance in the patterns autonomic nervous system (ANS) follows when reciprocally regulating cardiac system of a child. Such conditions lead to pronounced utilization of the cardiovascular system's compensatory mechanisms associated with the child's adaptation to physical and mental exertion [3, 6, 8, 9]. Mental and physical fatigue, emotional stress make the child psycho-emotionally strained and more vulnerable, which results in acceleration of the psychophysical and social deadaptation processes [2, 4, 7, 8].

In a considerable number of children, one part of ANS is functionally dominant, especially when the pressure coming from the environment exceeds the child's ability to adapt [4, $5,9,10]$. Changes in the regulatory action of higher nervous function and higher mental processes (HMP) that depend on the state of the central nervous system (CNS), brain and its cortex, alter the rate of conditioned reflex reactions, disrupt interaction between the first and the second signal systems, cause psychosomatic and behavioral deviations, etc. Children with such deviations belong to the group of conditionally healthy; their adaptation processes are considerably more intense than they normally are (premorbid, pre-nosological state), which can lead to a breakdown, primarily - disruption of regulatory links in the child's physiological processes, poor mental, physical and learning performance [1, 4, 6, 9, 11-14].

During ontogenesis, interaction patterns between the body's functional systems change dynamically, and the speed of such change grows due to acceleration. At the same time, the child develops mechanisms to adapt to physical and mental loads. Readjustment of the autonomic processes regulating body functions plays an important part in the development of these mechanisms $[4,8]$.

Understanding the age-related features of adaptation of children by their integrated psycho-physiological characteristics that change under the influence of learning activities would allow designing optimal educational environment and curriculum system for schoolchildren and enable development of the educational process psychological and pedagogical support methods. Such measures are called for by the major contradiction embedded into the current education system: accelerated intensification of studying (i.e., mental loads) leads to progression of deficit of physical activity (i.e., physical loads) initially caused by the changing regimens of children living in urbanized environments [4, 7, 15-17]. However, many integrative ontogenesis and age-related adaptation mechanisms influenced by studying and environment present day schoolchildren live in have not been researched sufficiently.

This study aimed to research the impact educational environment factors (mental arithmetic, physical exercise, attention switching) have on the development of physiological functions and cognitive processes in schoolchildren going through the most sensitive periods (ages 7-9 and 10-12) and studying intensely. The goals were: to assess the psychophysical development of younger schoolchildren and changes thereto under the influence of physical exercises implying attention switching (counting, arithmetic); to reveal the gender-specific differences in cognitive capabilities and physical functions of children aged 7-12; to study the effect physical exercise has on cognitive processes of younger children practicing mental arithmetic with their physiological specifics factored in.

\section{METHODS}

\section{Participating schoolchildren}

124 schoolchildren attending Eureka Intellectual Development Center (city of Togliatti) participated in the study, which lasted October 2017 through May 2018. They were 30 boys and 32 girls aged $7-9$ and 30 boys and 32 girls aged 10-12. Within each gender-age category, the children were divided into treatment groups (TG) and control groups (CG). While forming the groups, we aimed at making them relatively equal in terms of the initial psycho-physiological and cognitive characteristics.

\section{Ethical review}

The study was approved by the local ethics committee of Togliatti State University (protocol \#1 of 08.29.17). Parents of the schoolchildren submitted the informed consent forms allowing their children to participate in the experiment.

Inclusion criteria: ages 7 to 12; no medical contraindications to learning and physical activities. Exclusion criteria: acute infectious diseases and other medical contraindications to learning and physical activities. Parts of the brain responsible for cognition develop intensively at the age 7 through $9[13,14$, $18,19] .10$ through 12 , the process continues; this is also the period when the individual profile of lateral specialization of the brain hemispheres' functions completes its formation [11, 20].

\section{Mental arithmetic program}

All children were taught mental arithmetic for 6 months, 45 minute sessions twice a week. The skill was mastered with the help of abacus, a special arithmetic device; the children were doing the calculations mentally, without pen and paper. Individual characteristics and current psychophysical state defined how the participants of the experiment reacted to the mental stress. With the aim to optimize psychophysical indicators, TG children were also doing motor exercises implying attention switching (AS), an addition to the program not available to the CG participants.

\section{Physical exercises with attention switching activities}

The children were offered short breaks involving a combination of physical exercises and attention switching activities in the beginning, middle and end of their mental arithmetic lessons. The attention switching physical exercises were: 1) ball games; 2) counting while playing ball; 3) counting while jumping; 4) counting and answering questions while balancing on a board. The exercises help concentration, involve most muscles controlling the child's posture and strengthening leg tendons and ligaments, improve agility and motor coordination, promote development of perception and sensorimotor coordination. Mental arithmetic lessons combined with attention switching physical exercising (counting, doing arithmetic operations) stimulate psychomotor activity; the goal is to improve mental activity, extend the range and diversity of movements, develop dexterity, flexibility, speed, coordination ability. 


\section{Pedagogical experiment method}

The cognitive activity indicators were registered at the three stages of the pedagogical experiment:

1) benchmarking stage (October 2017): registration of the baseline indicators of the cardiovascular system functional status, adaptation capabilities, cognitive processes development level;

2) formation stage (December 2017 - April 2018): cognitive tasks and physical exercises used to develop motor skills and mental processes;

3) control stage (May 2018): registration of the resulting indicators after a number of lessons involving exercising designed to stimulate the children's mental and physical activity.

\section{Psychodiagnostic methods}

The psychodiagnostic program included the following psychological techniques:

1) short-term memory diagnostics (memorization of 10 words);

2) associative memory diagnostics (10 pair associations);

3) image memory diagnostics (16 images);

4) Bourdon-Wiersma test;

5) search for analogies and logical solutions;

6 ) evaluation of motor skills (children aged 7-12, metric scale [21-23].

Attention switching physical exercises were part of the TG lessons exclusively.

\section{Diagnostics of the functional parameters of the body}

Varicard 2.51 software and hardware system (Ramena Institute for Implementation of New Medical Technologies, Russia) was used to determine functional state of the children's CVS. We applied the heart rate variability analysis to register all the major parameters, including:

- autonomic regulation of blood flow with assessment of load on the body's regulatory systems;

- autonomic cardiac rhythm regulation (baseline autonomic regulation level, autonomic reactivity, autonomic support to activity);

- functional state of the body and changes thereto as registered through the vegetative balance and neurohumoral regulation indicators.

Based on the assessment of the body's functional state, intensity of its adaptation responses and status of the regulatory systems, we have compiled prognostic conclusions and developed recommendations that were used in this study and suggested for educational process [24].

\section{Methods of mathematical statistics}

We have applied the following mathematical statistics methods when processing the data obtained: Kolmogorov-Smirnov test (nonparametric test of the equality of continuous, onedimensional probability distributions) and parametric Student's t-test. The differences were considered statistically significant at $p<0.05$.

Kolmogorov-Smirnov test revealed that the studied variables fall within the limits of normality, which allowed applying the Student's $t$-test for interrelated and independent samples.

SPSS 17.0 for Windows was used to process the experimental data.
RESULTS

At the benchmarking of the study, the functional indicators of development of children (functional status of regulatory systems) from TG and CG were almost similar. It is known that even minor changes to the vegetative balance significantly affect schoolchildren's health, which translates into deterioration of their stress resistance and capability to adapt to physical and mental stress associated with studying.

Primary school age is characterized by fluctuating intersystem and intersystem relations (psycho-emotional, autonomic and hormonal-metabolic mechanisms). This leads to instability and degradation of the functional and adaptive capabilities, a result of the constant load put on the regulatory systems by learning activities [4, 6, 8].

To study the vegetative balance, we have registered functional status of the CVS with the help of the heart rhythm variability method.

At the beginning of the study, the stress index $(\mathrm{SI})$ was growing; this index reflects the degree of predominance of central regulation mechanisms over autonomic mechanisms. In the TG, the index was 298 conditional units, in the CG - 486 conditional units, which signals of the intensive action of the body's regulatory systems and reduced functional reserves. These results show that the increasing learning-related loads lead to mental and physical fatigue that disturbs the balance between sympathetic and parasympathetic parts of the nervous system. Children participating in the study were 7 to 12 years old; at this age, morphofunctional structures of the CNS are still immature, thus the strength and the equilibrium of the nervous processes are relatively minor, which can translate into rapid depletion of the cerebral cortex cells, fatigue and poor mental performance. It is necessary to have the children switch to another type of activity in a timely manner when they start feeling physical and mental fatigue.

In this connection, a combination of physical and mental exercises was added to the beginning, middle and end of their mental arithmetic lessons.

Also, at the benchmarking and control stages of the pedagogical experiment we have studied the children's (boys and girls, ages 7-9 and 10-12) memorization ability, attention concentration and switching capabilities, ideation and motor skills. The results were compared for the following age groups (Tables 1-4):

- 7-9 y.0.: TG (15 boys, 16 girls) and CG (15 boys, 16 girls);

- 10-12 y.o.: TG (15 boys, 16 girls) and CG (15 boys, 16 girls).

The results of memory, attention and ideation diagnostics done at the benchmarking stage show that girls aged 7-9 have better (by 20-40\%) short-term, associative and image memory, as well as concentration and attention switching capabilities than boys of the same age; see Tables 1, 2. These genderspecific differences result from the fact that ontogenetically, girls develop faster than boys [18, 19]. Girls have their first growth leap 0.5-1 year earlier than boys, so the development of their psychological capabilities, which is synchronized with morphofunctional development of the body, goes faster.

At the age of 10-12 years, boys are able to memorize, concentrate, switch attention and solve logic problems $10-30 \%$ better than girls (see Tables 3, 4); the difference is gender-specific, it is a result of the peculiarities of cerebral hemispheres lateral organization profiles [17, 18, 20], which, having developed completely, make the left hemisphere more active than the right, while in girls they are equipotential. 
This growth of mental activity indicators, determined by age and gender factors, signals of the growing morphofunctional readiness of the brain and mental processes to solve spatial and temporal problems [5, 20].

Having studied two age groups, we also found that girls have better motor capabilities than boys, which is the result of the former having various links of the motor analyzer (including higher cortical sections) better developed at this stage of ontogenesis.

At the benchmarking of the study, the functional indicators of development of children (functional status of regulatory systems) from TG and CG were almost similar. It is known that even minor changes to the vegetative balance significantly affect schoolchildren's health, which worsens their stress resistance and ability to adapt to physical and mental stress associated with studying $[2,6,9,10]$. To study these specifics, we determined the functional status of CVS through measuring variability of the heart rhythm.

When the formation stage of the pedagogical experiment was over, we examined the children's regulatory systems again. The results of these examinations show that TG participants, provided their days are scheduled correctly, benefit from physical exercise: the functional status of their bodies improves.

Table 5 shows how the heart rhythm changed in TG and CG participants at the control stage of the pedagogical experiment.

The data presented in Table 5 reflect stabilization of the functional processes; $\mathrm{Si}$ index (regulatory systems load) Table 1. Comparison of memory, attention, ideation and motor skills, in points, boys 7-9 y.o., TG and CG

\begin{tabular}{|c|c|c|c|c|c|c|c|c|}
\hline \multirow{2}{*}{\multicolumn{2}{|c|}{ Variables (functions) }} & \multicolumn{3}{|c|}{ Boys (benchmarking stage) } & \multicolumn{3}{|c|}{ Boys (control stage) } & \multirow{3}{*}{$\begin{array}{c}\begin{array}{c}\text { Student's } \\
t \text {-test }\end{array} \\
11.59^{* *}\end{array}$} \\
\hline & & \multirow{2}{*}{$\begin{array}{c}\text { Average } \\
4.27\end{array}$} & \multirow{2}{*}{$\begin{array}{c}\begin{array}{c}\text { Standard } \\
\text { deviation }\end{array} \\
1.67\end{array}$} & \multirow{2}{*}{$\begin{array}{c}\begin{array}{c}\text { Standard error } \\
\text { of mean }\end{array} \\
0.43\end{array}$} & \multirow{2}{*}{$\begin{array}{c}\text { Average } \\
8.9\end{array}$} & \multirow{2}{*}{$\begin{array}{c}\begin{array}{c}\text { Standard } \\
\text { deviation }\end{array} \\
1.27\end{array}$} & \multirow{2}{*}{$\begin{array}{c}\begin{array}{c}\text { Standard error } \\
\text { of mean }\end{array} \\
0.33\end{array}$} & \\
\hline Short-torm momor & $\mathrm{TG}$ & & & & & & & \\
\hline & CG & 4.20 & 1.64 & 0.42 & 6.3 & 1.29 & 0.33 & $2.18^{\star}$ \\
\hline \multirow{2}{*}{ Associative memory } & $\mathrm{TG}$ & 11.07 & 4.46 & 1.15 & 17.09 & 3.41 & 0.88 & $6.87^{\star \star}$ \\
\hline & $C G$ & 11.07 & 4.37 & 1.13 & 12.00 & 3.37 & 0.87 & $2.68^{*}$ \\
\hline \multirow{2}{*}{ Image memory } & $\mathrm{TG}$ & 7.60 & 1.68 & 0.43 & 15.60 & 1.08 & 0.28 & $11.77^{\star \star}$ \\
\hline & $C G$ & 7.51 & 1.65 & 0.43 & 12.40 & 1.60 & 0.41 & $2.27^{*}$ \\
\hline \multirow{2}{*}{ Attention concentration } & $\mathrm{TG}$ & 13.79 & 6.72 & 1.74 & 20.79 & 3.02 & 0.78 & $5.87^{\star \star}$ \\
\hline & $\mathrm{CG}$ & 13.70 & 6.69 & 1.73 & 16.70 & 5.99 & 1.55 & $2.88^{*}$ \\
\hline \multirow{2}{*}{ Attention switching } & TG & 5.19 & 2.13 & 0.55 & 4.19 & 2.03 & 0.52 & $2.79^{*}$ \\
\hline & $C G$ & 5.20 & 2.11 & 0.54 & 5.00 & 2.01 & 0.52 & 1.69 \\
\hline \multirow{2}{*}{ Search for analogies } & TG & 6.60 & 3.11 & 0.80 & 9.60 & 3.31 & 0.85 & $5.35^{\star \star}$ \\
\hline & CG & 6.61 & 3.10 & 0.80 & 7.50 & 3.50 & 0.90 & 1.62 \\
\hline \multirow{2}{*}{ Logical tasks solving } & TG & 14.00 & 8.33 & 2.15 & 19.60 & 3.30 & 0.85 & $9.45^{\star \star}$ \\
\hline & $\mathrm{CG}$ & 14.01 & 8.90 & 2.30 & 16.00 & 5.90 & 1.52 & $2.17^{\star}$ \\
\hline \multirow{2}{*}{ Motor skills } & TG & 1.80 & 0.94 & 0.24 & 4.1 & 0.54 & 0.14 & $11.56^{\star \star}$ \\
\hline & $C G$ & 1.80 & 0.88 & 0.23 & 3.5 & 0.59 & 0.15 & $2.45^{\star}$ \\
\hline
\end{tabular}

Note: * - significance level $p \leq 0.05 ;{ }^{* *}$ - significance level $p \leq 0.01$

Table 2. Comparison of memory, attention, ideation and motor skills, in points, girls 7-9 y.o., TG and CG

\begin{tabular}{|c|c|c|c|c|c|c|c|c|}
\hline \multirow{2}{*}{\multicolumn{2}{|c|}{ Variables (functions) }} & \multicolumn{3}{|c|}{ Girls (benchmarking stage) } & \multicolumn{3}{|c|}{ Girls (control stage) } & \multirow{3}{*}{$\begin{array}{c}\begin{array}{c}\text { Student's } \\
\text { t-test }\end{array} \\
11.90^{\star \star}\end{array}$} \\
\hline & & \multirow{2}{*}{$\begin{array}{c}\text { Average } \\
5.27\end{array}$} & \multirow{2}{*}{$\begin{array}{c}\text { Standard deviation } \\
1.27\end{array}$} & \multirow{2}{*}{$\begin{array}{c}\begin{array}{c}\text { Standard error } \\
\text { of mean }\end{array} \\
0.32\end{array}$} & \multirow{2}{*}{$\begin{array}{c}\text { Average } \\
9.51\end{array}$} & \multirow{2}{*}{$\begin{array}{c}\text { Standard deviation } \\
1.63\end{array}$} & \multirow{2}{*}{$\begin{array}{c}\begin{array}{c}\text { Standard error } \\
\text { of mean }\end{array} \\
0.41\end{array}$} & \\
\hline Chout torm momon & TG & & & & & & & \\
\hline 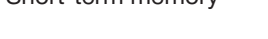 & CG & 5.20 & 1.09 & 0.27 & 7.20 & 1.67 & 0.42 & $2.21^{*}$ \\
\hline \multirow{2}{*}{ Associative memory } & TG & 15.00 & 3.85 & 0.96 & 19.00 & 2.85 & 0.71 & $4.61^{\star \star}$ \\
\hline & CG & 14.01 & 2.62 & 0.66 & 14.01 & 3.60 & 0.90 & 2.05 \\
\hline \multirow{2}{*}{ Image memory } & TG & 10.82 & 2.75 & 0.69 & 15.12 & 2.15 & 0.54 & $5.9^{\star *}$ \\
\hline & CG & 10.90 & 2.64 & 0.66 & 11.00 & 2.34 & 0.59 & $2.34^{*}$ \\
\hline \multirow{2}{*}{ Attention concentration } & TG & 20.92 & 6.83 & 1.71 & 26.92 & 3.43 & 0.86 & $3.11^{\star \star}$ \\
\hline & CG & 20.80 & 6.87 & 1.72 & 24.80 & 5.87 & 1.47 & $2.52^{*}$ \\
\hline \multirow{2}{*}{ Attention switching } & TG & 4.75 & 2.39 & 0.60 & 3.60 & 1.39 & 0.35 & $2.71^{*}$ \\
\hline & CG & 4.61 & 2.40 & 0.60 & 4.10 & 1.40 & 0.35 & 2.11 \\
\hline \multirow{2}{*}{ Search for analogies } & TG & 8.73 & 2.61 & 0.65 & 11.5 & 2.41 & 0.60 & $4.03^{\star *}$ \\
\hline & CG & 8.62 & 2.51 & 0.63 & 8.70 & 2.50 & 0.63 & 1.86 \\
\hline \multirow{2}{*}{ Logical tasks solving } & $\mathrm{TG}$ & 18.82 & 6.28 & 1.57 & 26.80 & 3.28 & 0.82 & $7.09^{\star \star}$ \\
\hline & CG & 18.91 & 5.47 & 1.37 & 22.90 & 5.75 & 1.44 & 2.02 \\
\hline \multirow{2}{*}{ Motor skills } & TG & 2.82 & 0.75 & 0.19 & 3.40 & 4.50 & 1.13 & $8.91^{\star *}$ \\
\hline & CG & 2.81 & 0.75 & 0.19 & 2.91 & 4.75 & 1.19 & $2.71^{\star}$ \\
\hline
\end{tabular}

Note: ${ }^{*}$ - significance level $p \leq 0.05 ;{ }^{* *}$ - significance level $p \leq 0.01$ 
values and heart rate of the TG schoolchildren are close to the physiological norm. Regulation systems work normally, body copes with stress in an optimal way, its systems are stable, which proves that the combination of mental and physical exercising and lessons' regime are correct.

By the end of the study, CG participants had high Si, tachycardia, their regulatory systems were highly active and functional reserves of the body decreased (Table 5). In such a condition, the regulatory systems are overstressed. Prolonged overstress associated with studying can compromise physiological adaptation and trigger the pathogenic chain reaction: disadaptation - pre-existing disease — development of diseases - chronic pathologies. To avoid such situations, it is necessary to organize the child's day regimen correctly, allocate mental and physical exercising rationally and introduce motor activities to the schedule properly, which is proved by the data shown in Tables 6, 7 and Figures 1, 2.

When the formation stage of the pedagogical experiment was over, we tested regulatory systems of the participants again. The results of these tests prove that introduction of physical exercising to the mental arithmetic lessons in TG translates into optimization of the schoolchildren's movements regime. Therefore, functional status of TG participants improves (Fig. 1, Table 6), as opposed to that of CG participants (Fig. 2, Table 2), with the applicable indicators growing accordingly. Here, it is important to note the effect attention switching physical exercises had on Si: it decreased 1.8 times. Figures 3, 4 show the data backing the results.

Table 3. Comparison of memory, attention, ideation and motor skills, in points, boys 10-12 y.o., TG and CG

\begin{tabular}{|c|c|c|c|c|c|c|c|c|}
\hline \multirow{2}{*}{\multicolumn{2}{|c|}{ Variables (functions) }} & \multicolumn{3}{|c|}{ Boys (benchmarking stage) } & \multicolumn{3}{|c|}{ Boys (control stage) } & \multirow{3}{*}{$\begin{array}{c}\begin{array}{c}\text { Student's } \\
t \text {-test }\end{array} \\
6.59^{\star \star}\end{array}$} \\
\hline & & \multirow{2}{*}{$\begin{array}{c}\text { Average } \\
6.63\end{array}$} & \multirow{2}{*}{$\begin{array}{c}\begin{array}{c}\text { Standard } \\
\text { deviation }\end{array} \\
1.41\end{array}$} & \multirow{2}{*}{$\begin{array}{c}\begin{array}{c}\text { Standard error } \\
\text { of mean }\end{array} \\
0.36\end{array}$} & \multirow{2}{*}{$\begin{array}{c}\text { Average } \\
9.50\end{array}$} & \multirow{2}{*}{$\begin{array}{c}\begin{array}{c}\text { Standard } \\
\text { deviation }\end{array} \\
0.53\end{array}$} & \multirow{2}{*}{$\begin{array}{c}\begin{array}{c}\text { Standard error } \\
\text { of mean }\end{array} \\
0.14\end{array}$} & \\
\hline Shoutom mama & $\mathrm{TG}$ & & & & & & & \\
\hline 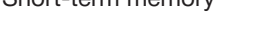 & CG & 6.50 & 1.53 & 0.40 & 7.60 & 0.89 & 0.23 & 2.13 \\
\hline \multirow{2}{*}{ Associative memory } & $\mathrm{TG}$ & 16.13 & 1.73 & 0.45 & 19.40 & 0.73 & 0.19 & $4.87^{\star \star}$ \\
\hline & $\mathrm{CG}$ & 15.08 & 1.74 & 0.45 & 15.09 & 0.84 & 0.22 & 1.96 \\
\hline \multirow{2}{*}{ Image memory } & TG & 10.38 & 2.45 & 0.63 & 15.40 & 0.74 & 0.19 & $7.17^{\star \star}$ \\
\hline & CG & 10.30 & 2.74 & 0.71 & 13.30 & 1.02 & 0.26 & $2.29^{*}$ \\
\hline \multirow{2}{*}{ Attention concentration } & $\mathrm{TG}$ & 27.25 & 7.36 & 1.90 & 34.00 & 4.31 & 1.11 & $4.84^{\star \star}$ \\
\hline & CG & 27.40 & 6.89 & 1.78 & 29.40 & 6.43 & 1.66 & $2.18^{\star}$ \\
\hline \multirow{2}{*}{ Attention switching } & TG & 5.60 & 1.80 & 0.46 & 3.40 & 0.97 & 0.25 & $4.12^{\star \star}$ \\
\hline & CG & 5.80 & 1.94 & 0.50 & 4.20 & 1.14 & 0.29 & $2.69^{*}$ \\
\hline \multirow{2}{*}{ Search for analogies } & $\mathrm{TG}$ & 9.25 & 1.98 & 0.51 & 12.00 & 0.04 & 0.01 & $2.99^{* *}$ \\
\hline & CG & 9.40 & 1.90 & 0.49 & 10.5 & 1.01 & 0.26 & $2.62^{*}$ \\
\hline \multirow{2}{*}{ Logical tasks solving } & $\mathrm{TG}$ & 23.75 & 5.57 & 1.44 & 28.90 & 1.80 & 0.46 & $3.44^{* *}$ \\
\hline & $C G$ & 23.88 & 5.81 & 1.50 & 24.60 & 2.09 & 0.54 & $2.19^{*}$ \\
\hline \multirow{2}{*}{ Motor skills } & $\mathrm{TG}$ & 2.25 & 0.71 & 0.18 & 4.10 & 0.14 & 0.04 & $5.71^{\star \star}$ \\
\hline & CG & 2.30 & 0.65 & 0.17 & 3.80 & 0.36 & 0.09 & $2.49^{*}$ \\
\hline
\end{tabular}

Note: ${ }^{*}$ - significance level $p \leq 0.05 ;{ }^{* \star}$ - significance level $p \leq 0.01$.

Table 4. Comparison of memory, attention, ideation and motor skills, in points, girls 10-12 y.o., TG and CG

\begin{tabular}{|c|c|c|c|c|c|c|c|c|}
\hline \multirow{2}{*}{\multicolumn{2}{|c|}{ Variables (functions) }} & \multicolumn{3}{|c|}{ Girls (benchmarking stage) } & \multicolumn{3}{|c|}{ Girls (control stage) } & \multirow{2}{*}{$\begin{array}{c}\text { Student's } \\
t \text {-test }\end{array}$} \\
\hline & & Average & $\begin{array}{l}\text { Standard } \\
\text { deviation }\end{array}$ & $\begin{array}{l}\text { Standard error } \\
\text { of mean }\end{array}$ & Average & $\begin{array}{l}\text { Standard } \\
\text { deviation }\end{array}$ & $\begin{array}{l}\text { Standard error } \\
\text { of mean }\end{array}$ & \\
\hline \multirow{2}{*}{ Short-term memory } & TG & 5.80 & 1.30 & 0.33 & 9.60 & 0.54 & 0.14 & $6.50^{\star \star}$ \\
\hline & CG & 5.71 & 1.55 & 0.39 & 6.60 & 1.05 & 0.26 & $2.34^{*}$ \\
\hline \multirow{2}{*}{ Associative memory } & TG & 14.40 & 2.61 & 0.65 & 19.60 & 0.54 & 0.14 & $5.98^{\star \star}$ \\
\hline & CG & 14.49 & 2.55 & 0.64 & 14.00 & 0.95 & 0.24 & 2.09 \\
\hline \multirow{2}{*}{ Image memory } & $\mathrm{TG}$ & 9.60 & 2.07 & 0.52 & 14.30 & 0.51 & 0.13 & $8.19^{\star *}$ \\
\hline & CG & 9.70 & 1.55 & 0.39 & 10.10 & 0.75 & 0.19 & $2.19^{*}$ \\
\hline \multirow{2}{*}{ Attention concentration } & TG & 23.60 & 4.51 & 1.13 & 37.00 & 3.31 & 0.83 & $4.21^{\star \star}$ \\
\hline & CG & 23.50 & 4.95 & 1.24 & 30.60 & 4.45 & 1.11 & $2.59^{*}$ \\
\hline \multirow{2}{*}{ Attention switching } & $\mathrm{TG}$ & 4.80 & 1.36 & 0.34 & 3.10 & 0.69 & 0.17 & $3.71^{\star \star}$ \\
\hline & CG & 4.80 & 1.33 & 0.33 & 4.00 & 1.11 & 0.28 & $2.16^{*}$ \\
\hline \multirow{2}{*}{ Search for analogies } & TG & 9.80 & 1.64 & 0.41 & 12.00 & 0.06 & 0.02 & $5.13^{\star \star}$ \\
\hline & CG & 9.80 & 1.56 & 0.39 & 10.1 & 1.14 & 0.29 & $2.56^{\star}$ \\
\hline \multirow{2}{*}{ Logical tasks solving } & $\mathrm{TG}$ & 22.00 & 3.74 & 0.94 & 28.40 & 0.54 & 0.14 & $9.01^{* *}$ \\
\hline & CG & 23.40 & 3.55 & 0.89 & 26.20 & 1.34 & 0.34 & $2.32^{*}$ \\
\hline \multirow{2}{*}{ Motor skills } & TG & 2.60 & 0.89 & 0.22 & 4.20 & 0.21 & 0.05 & $11.91^{\star *}$ \\
\hline & CG & 2.70 & 0.84 & 0.21 & 3.60 & 0.83 & 0.21 & $2.82^{*}$ \\
\hline
\end{tabular}

Note: ${ }^{*}$ - significance level $p \leq 0.05 ;{ }^{* \star}$ - significance level $p \leq 0.01$. 
By the end of the study, we registered differences in functional class of $T G$ and $C G$ schoolchildren. That of $T G$ is second, which is the functional class peculiar to normal operation of systems supporting a developing organism. This fact confirms the necessity to switch types of activities during mental arithmetic lessons, namely - do attention switching physical exercises. Switch to other types of mental and physical activities: 1) activates CNS; 2) prevents monotony; 3) shifts attention and softens the tiring effect of studying (Fig. 3).

Functional class of CG participants is 6, which signals of the children's regulatory systems being overstressed (Fig. 4). Such a situation invites consideration of activity switching breaks as part of the lessons. Such breaks would help to prevent overstrain and depletion of the body's adaptation reserves, thus preserving health of schoolchildren while their academic loads grow.

Thus, the study confirms that incorporation of the attention switching physical exercises into mental arithmetic curricula improves mental performance and psychomotor capabilities of younger schoolchildren.

\section{DISCUSSION}

Many researchers, such as N. I. Shlyk, R. M. Baevsky, E. D. Sinyak, D. L. Sonkin and others, are studying physiological adaptation of a child's organism to learning activities. Their research focuses on reasoning the methods of selection of physical movement loads adequate to both training and physical culture lessons with the children's physical abilities factored in. In this study, we have also considered the psychophysical indicators that allow allocating schoolchildren to certain functional classes. However, it is important to utilize the high playing potential of children [25]. With this is mind, we introduced the attention switching physical exercises into mental arithmetic lessons, which made the latter more exciting.

In the context of the study conducted, attention switching physical exercising added to the mental arithmetic lessons improved HMP of younger schoolchildren: they showed better memorizing abilities (short-term, associative, image memory), their voluntary attention, ideation and motor skills improved. It can be assumed that the positive dynamics of HMP are the result of prevention of monotony and optimization of balance of excitation/inhibition processes in the cerebral cortex.

Memory, attention and motor skills testing shows their improvement by a factor of 1.5-2 after incorporation of physical exercises into the mental arithmetic curricula. This growth of functional indicators under the influence of attention switching physical exercises confirms they contribute to psychomotor development of younger schoolchildren.

Table 5. Heart rhythm indicators, control stage, pedagogical experiment, TG and CG

\begin{tabular}{|l|c|c|c|}
\hline \multicolumn{1}{|c|}{ Name } & TG & CG & Norm \\
\hline Heart rate (HR), beats/min. & 71 & 51.4 & $55-80$ \\
\hline Standard deviation (SDNM), ms & 55.8 & 7.9 & $30-100$ \\
\hline Variation coefficient (VC), \% & 6.6 & $227^{\star *}$ & $3-12$ \\
\hline Stress index (SI), c.u. & 114 & $1.3^{\star *}$ & $50-150$ \\
\hline Index of centralization (IC), c.u. & $1.3^{\star \star}$ & $6^{\star}$ & $2-8$ \\
\hline Atypy index, c.u. & 2 & $1-3$ \\
\hline
\end{tabular}

Note: ${ }^{*}$ - significance level $p \leq 0.05 ;{ }^{* \star}$ - significance level $p \leq 0.01$.

Table 6. Regulatory systems indicators, control stage, pedagogical experiment, TG

\begin{tabular}{|c|c|}
\hline \multicolumn{2}{|l|}{ Functioning level } \\
\hline Moderate bradycardia & -1 \\
\hline \multicolumn{2}{|l|}{ Regulation stability } \\
\hline Normal rhythm stability & 0 \\
\hline \multicolumn{2}{|l|}{ Vegetative homeostasis } \\
\hline Normal vegetative balance & 0 \\
\hline \multicolumn{2}{|l|}{ Sympathetic vascular center activity } \\
\hline Normal activity of vascular center & 0 \\
\hline \multicolumn{2}{|l|}{ Regulation centralization degree } \\
\hline Central regulation levels - moderate decrease in activity & -1 \\
\hline
\end{tabular}

Table 7. Regulatory systems indicators, control stage, pedagogical experiment, CG

\begin{tabular}{|c|c|}
\hline \multicolumn{2}{|l|}{ Functioning level } \\
\hline Severe tachycardia & 2 \\
\hline \multicolumn{2}{|l|}{ Regulation stability } \\
\hline Normal rhythm stability & 0 \\
\hline \multicolumn{2}{|l|}{ Vegetative homeostasis } \\
\hline Moderate predominance of sympathetic nervous system & 1 \\
\hline \multicolumn{2}{|l|}{ Sympathetic vascular center activity } \\
\hline Moderately increased activity of vascular center & 1 \\
\hline \multicolumn{2}{|l|}{ Regulation centralization degree } \\
\hline Central regulation levels - sharp decrease in activity & -2 \\
\hline
\end{tabular}

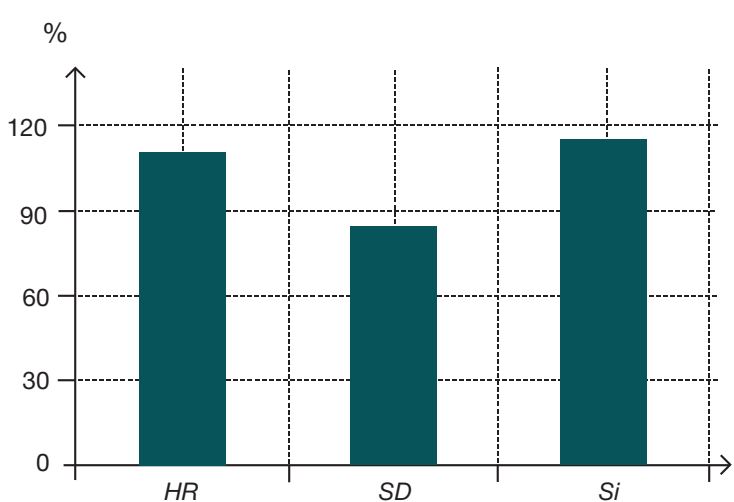

Fig. 1. Heart rhythm indicators, control stage, pedagogical experiment, TG: $H R$ - heart rate, beats/min.; SD — standard deviation, $\mathrm{ms}$; Si — stress index, c.u.

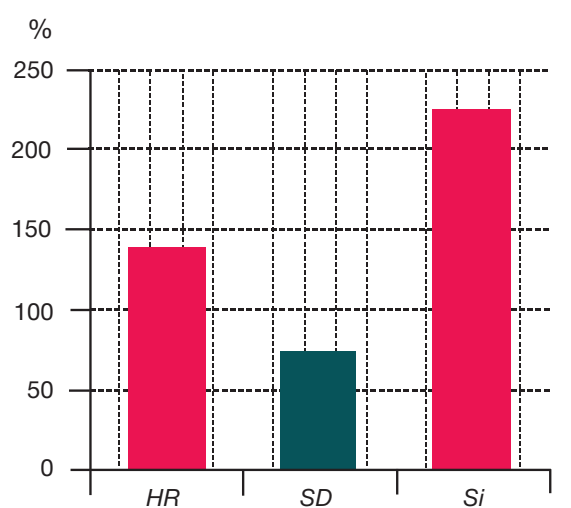

Fig. 2. Heart rhythm indicators, control stage, pedagogical experiment, CG: $H R$ - heart rate, beats/min.; SD — standard deviation, $\mathrm{ms}$; Si — stress index, c.u. 


\section{Atypy index}

Normal level

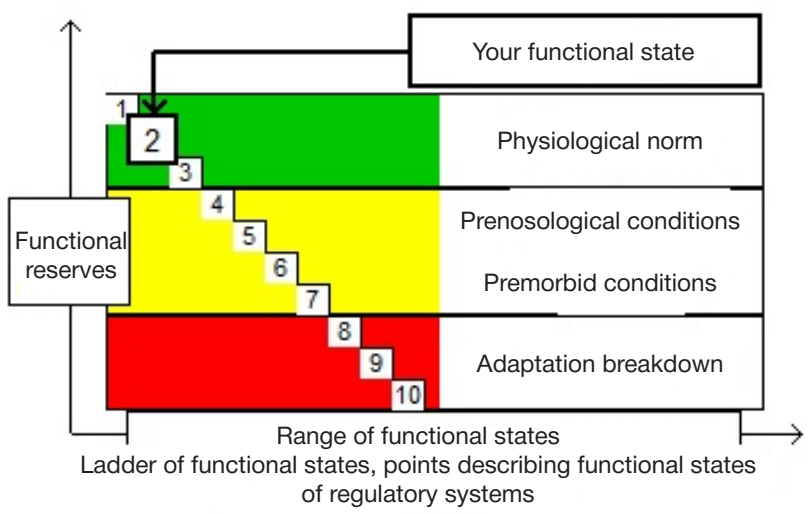

Fig. 3. Functional class diagram, TG, control stage, pedagogical experiment

Comparing the results obtained at benchmarking and control stages of the pedagogical experiment, we found the differences between them to be statistically significant $(p \leq 0.05$, all considered parameters).

Combination of mental and physical exercises prevented fatigue, normalized status of the body's regulatory systems and triggered restorative processes. The results show that TG participants, provided their days are scheduled correctly, benefit from physical exercise: the functional status of their bodies improves. A number of researchers stress the importance of fatigue prevention in children; in the long run, associated practices help to improve their health and learning performance, maintaining their CNS and ANS activity at the levels optimal for adequate functioning of the body on the whole in the context of studying $[2-4,8]$. Another important observation made by the researchers is the correlation of functional status and disadaptation risk: the closer the former to the norm, the lower the latter.

Research of the causes of heterogeneity and instability of neurohumoral regulation of heart rate in children that results from constitutional genetic imbalance in AMS maturation at the certain stage of ontogenesis revealed that the mechanisms of adaptive reactions are best stabilized when the child's regime is in order (motor activity, day schedule, nutrition, sleep, psychoemotional activity control) $[1,8,10]$.

General state of the child's health should be taken into account when designing practices to improve his or her mental and physical performance. It is known that lessons without dynamic activities tend to tire children quicker. Thus, mental
Atypy index

Regulatory mechanisms overstress

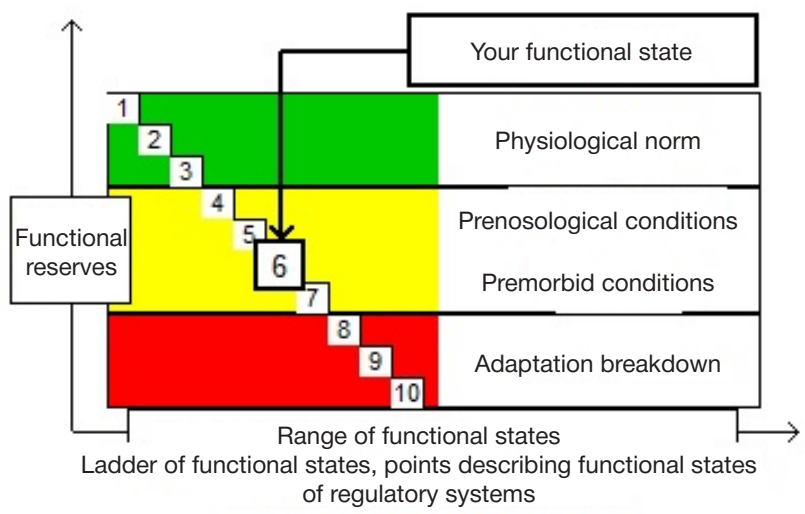

Fig. 4. Functional class diagram, CG, control stage, pedagogical experiment arithmetic sessions should be short and supplemented by physical activities implying playing and attention switching, including ball games, jumps, balancing on a board, counting while playing with a ball and jumping a rope. The research conducted confirms that such exercising improves mental performance and psychomotor capabilities of younger schoolchildren.

\section{CONCLUSIONS}

Comparison of the HMP indicators at the beginning of the study revealed gender-specific differences in children aged 7-9. Cognitive processes and motor skills of girls, whose ontogenetic development is faster at this age, are $20-40 \%$ better than those of boys. At the age of 10-12 years, higher mental functions and motor skills of boys are 10-30\% better than those of girls, which is the result of gender-specific activation of left hemisphere.

In TG, incorporation of attention switching physical exercises into mental arithmetic lessons improved the children's cognitive processes, attention, motor skills, adaptation and stress resistance abilities, and optimized functions of the body's regulatory systems; the improvement was statistically significant. In CG, which had mental arithmetic lessons without physical exercises, no pronounced improvement of cognitive processes and operation of functional systems of the body was observed. The results of this study allow recommending incorporation of the attention switching physical exercises into mental arithmetic lessons.

\section{References}

1. Krivolapchuk IA, Gerasimova AA, Chernova MB, Myshjakov W. Ishodnyj vegetativnyj tonus u detej v nachal'nyj period adaptacii $k$ obrazovatel'noj srede. Novye issledovanija. 2017; 2 (51): 12-21.

2. Krivolapchuk IA, Zajceva GA, Krivolapchuk II, Buslakov AP, Nosova RM, Bondareva SA. Stressovaja reaktivnost' serdechnososudistoj sistemy u shkol'nikov v period vtorogo detstva. Novye issledovanija. 2014; 3 (40): 20-30.

3. Sitdikov FG, Samigulin GH. Vozrastnye osobennosti nedel'noj dinamiki funkcional'nogo sostojanija organizma mladshih shkol'nikov. Fiziologija cheloveka. 2000; 26 (6): 167-9.

4. Potupchik TV, Makarova MV, Prahin El, Jevert LS, Bakshaeva SS, Shhegrova NA. Sposob prognoza adaptacii $k$ shkole $s$ ispol'zovaniem analiza variabel'nosti serdechnogo ritma. Mat' ditja v Kuzbasse. 2012; (4): 32-6.

5. Vygotskij LS. Psihologija razvitija rebenka. M.: Jeksmo, 2005.

6. Sitdikov FG, Ishakova AT, Kuznecova NO. Vlijanie fizicheskoj nagruzki na jelektrolitnyj i vegetativnyj balans detej 7-10 let. Teorija i praktika fizicheskoj kul'tury. 2009; (10): 25-7.

7. Dogadkina SB. Osobennosti vegetativnoj reguljacii serdechnogo ritma u detej 8 let. Novye issledovanija. 2011; 1 (27): 101-8.

8. Shlyk NI. Serdechnyj ritm i tip reguljacii u detej, podrostkov i sportsmenov. Izhevsk: Udmurtskij gos. un-t, 2009. 5-254.

9. Kuznecova OV, Sonkin VD. Vegetativnyj tonus $v$ zven'jah respiratorno-gemodinamicheskoj sistemy $u$ detej mladshego shkol'nogo vozrasta. Fiziologija cheloveka. 2009; 35 (6): 94-102.

10. Sitdikov FG, Shejhelislamova MV. Gormanal'nyj status i vegetativnyj tonus u detej 7-15 let. Kazan': TGGPU, 2008; $147 \mathrm{~s}$.

11. Rozental SG, Safina Al. Sravnitel'nyj analiz umstvennoj 
rabotosposobnosti $v$ raznyh vozrastnyh gruppah. Uchen. zap. Kazanskogo universiteta. Serija: Estestvennye nauki. 2015; 157 (3): 144-50.

12. Mjakotnyh W, Hodasevich LS. Vozrastnaja dinamika umstvennoj rabotosposobnosti pri razlichnyh rezhimah dvigatel'noj aktivnosti. Voprosy kurortologii, fizioterapii i lechebnoj fizicheskoj kul'tury. 2012; (3): 39-42.

13. Zvjagina NV, Morozova LV. Vozrastnye osobennosti umstvennoj rabotosposobnosti i vnimanija u detej i podrostkov goroda Arhangel'ska. Novye issledovanija. 2011; 1 (26): 66-76.

14. Dubrovina IV, Andreeva AD, Dubrovina IV i dr. Mladshij shkol'nik: razvitie poznavatel'nyh sposobnostej. M.: Prosveshhenie, 2003.

15. Pseunok AA. Fiziologicheskaja adaptacija detej mladshego shkol'nogo vozrasta k novym obrazovatel'nym modeljam obuchenija. Izvestija vysshih uchebnyh zavedenij. SeveroKavkazskij region. Serija: Estestvennye nauki. 2005; 1 (129): 65-8.

16. Lurija AR, Cvetkova LS. Nejropsihologija i problemy obuchenija v obshheobrazovatel'noj shkole. Voronezh: MODJeK, 1997.

17. Kulagina IJu. Mladshie shkol'niki: osobennosti razvitija. M.: Jeksmo, 2009; 169 s.

18. Koposova TS, Zvjagina NV, Morozova LV. Psihofiziologicheskie osobennosti razvitija detej mladshego shkol'nogo vozrasta.
Arhangel'sk: Izd-vo Pomor. un-ta, 1997; 159 s.

19. Ahutina TV, Melikjan ZA, Niznajko NN. Osobennosti vnimanija u mladshih shkol'nikov po dannym komp'juternogo issledovanija. Vestnik Moskovskogo universiteta. Serija 14: Psihologija. 1999; (4): $36-48$.

20. Vygotskij LS. Psihologija i uchenie o lokalizacii vysshih psihicheskih funkcij V knige: ED Homskaja, redaktor. Hrestomatija po nejropsihologii. M.: In-t obshhegumanitarnyh issledovanij; Moskovskij psihologo-social'nyj institut, 2004; 91-7.

21. Golovej LA, Rybalko EF, redaktory. Praktikum po vozrastnoj psihologii: Uchebnoe posobie. SPb.: Rech', 2005; 688 s.

22. Kuleshov LV. Psihologicheskoe obsledovanie: metodicheskoe rekomendacii. SPb.: Rech', 2001.

23. Venger AL, Cukerman GA. Psihologicheskoe obsledovanie mladshih shkol'nikov. M.: VLADOS-PRESS, 2005; $159 \mathrm{~s}$.

24. Semenov JuH, Baevskij RM. Apparatno-programmnyj kompleks "Varikard» dlja ocenki funkcional'nogo sostojanija organizma po rezul'tatam matematicheskogo analiza ritma serdca. Variabel'nost' serdechnogo ritma. Izhevsk, 1996; 160-2.

25. Vajsvalavechene VJu. Struktura sredstv, metodov i uslovij razvitija dvigatel'nyh sposobnostej u detej starshego doshkol'nogo vozrasta 5-7 let [dissertacija]. M., 2015.

\section{Литература}

1. Криволапчук И. А., Герасимова А. А., Чернова М. Б., Мышьяков В. В. Исходный вегетативный тонус у детей в начальный период адаптации к образовательной среде. Новые исследования. 2017; 2 (51): 12-21.

2. Криволапчук И. А., Зайцева Г. А, Криволапчук И. И., Буслаков А. П., Носова Р. М., Бондарева С. А. Стрессовая реактивность сердечно-сосудистой системы у школьников в период второго детства. Новые исследования. 2014; 3 (40): 20-30.

3. Ситдиков Ф. Г., Самигулин Г. Х. Возрастные особенности недельной динамики функционального состояния организма младших школьников. Физиология человека. 2000; 26 (6): 167-9.

4. Потупчик Т. В., Макарова М. В., Прахин Е. И., Эверт Л. С., Бакшаева С. С., Щегрова Н. А. Способ прогноза адаптации к школе с использованием анализа вариабельности сердечного ритма. Мать и дитя в Кузбассе. 2012; (4): 32-6.

5. Выготский Л. С. Психология развития ребенка. М.: Эксмо, 2005.

6. Ситдиков Ф. Г., Исхакова А. Т., Кузнецова Н. О. Влияние физической нагрузки на электролитный и вегетативный баланс детей 7-10 лет. Теория и практика физической культуры. 2009; (10): 25-7.

7. Догадкина С. Б. Особенности вегетативной регуляции сердечного ритма у детей 8 лет. Новые исследования. 2011; 1 (27): 101-8

8. Шлык Н. И. Сердечный ритм и тип регуляции у детей, подростков и спортсменов. Ижевск: Удмуртский гос. ун-т, 2009. 5-254

9. Кузнецова О. В., Сонькин В. Д. Вегетативный тонус в звеньях респираторно-гемодинамической системы у детей младшего школьного возраста. Физиология человека. 2009; 35 (6): 94 102.

10. Ситдиков Ф. Г., Шейхелисламова М.В.Горманальный статус и вегетативный тонус у детей 7-15 лет. Казань: ТГГПУ, 2008; 147 c.

11. Розенталь С. Г., Сафина А. И. Сравнительный анализ умственной работоспособности в разных возрастных группах. Учен. зап. Казанского университета. Серия: Естественные науки. 2015; 157 (3): 144-50.

12. Мякотных В. В., Ходасевич Л. С. Возрастная динамика умственной работоспособности при различных режимах двигательной активности. Вопросы курортологии, физиотерапии и лечебной физической культуры. 2012; (3): 39-42.
13. Звягина Н. В. Морозова Л. В. Возрастные особенности умственной работоспособности и внимания у детей и подростков города Архангельска. Новые исследования. 2011; 1 (26): 66-76.

14. Дубровина И. В., Андреева А. Д., Дубровина И. В. и др. Младший школьник: развитие познавательных способностей. М.: Просвещение, 2003.

15. Псеунок А. А. Физиологическая адаптация детей младшего школьного возраста к новым образовательным моделям обучения. Известия высших учебных заведений. СевероКавказский регион. Серия: Естественные науки. 2005; 1 (129): 65-8.

16. Лурия А. Р., Цветкова Л. С. Нейропсихология и проблемы обучения в общеобразовательной школе. Воронеж: МОДЭК, 1997

17. Кулагина И. Ю. Младшие школьники: особенности развития. М.: Эксмо, 2009; 169 с.

18. Копосова Т. С., Звягина Н. В., Морозова Л. В. Психофизиологические особенности развития детей младшего школьного возраста. Архангельск: Изд-во Помор. ун-та, 1997; 159 с.

19. Ахутина Т. В., Меликян З. А., Низнайко Н. Н. Особенности внимания у младших школьников по данным компьютерного исследования. Вестник Московского университета. Серия 14: Психология. 1999; (4): 36-48.

20. Выготский Л. С. Психология и учение о локализации высших психических функций. В книге: Е. Д. Хомская, редактор. Хрестоматия по нейропсихологии. М.: Ин-Т общегуманитарных исследований; Московский психологосоциальный институт, 2004; 91-7.

21. Головей Л. А., Рыбалко Е. Ф., редакторы. Практикум по возрастной психологии: Учебное пособие. СПб.: Речь, 2005; $688 \mathrm{c}$.

22. Кулешов Л. В. Психологическое обследование: методическое рекомендации. СПб.: Речь, 2001

23. Венгер А. Л., Цукерман Г. А. Психологическое обследование младших школьникОв. М.: ВЛАДОС-ПРЕСС, 2005; 159 с.

24. Семенов Ю. Н., Баевский Р. М. Аппаратно-программный комплекс «Варикард» для оценки функционального состояния организма по результатам математического анализа ритма сердца. Вариабельность сердечного ритма. Ижевск, 1996; 160-2.

25. Вайсвалавечене В. Ю. Структура средств, методов и условий развития двигательных способностей у детей старшего дошкольного возраста 5-7 лет [диссертация]. М., 2015. 